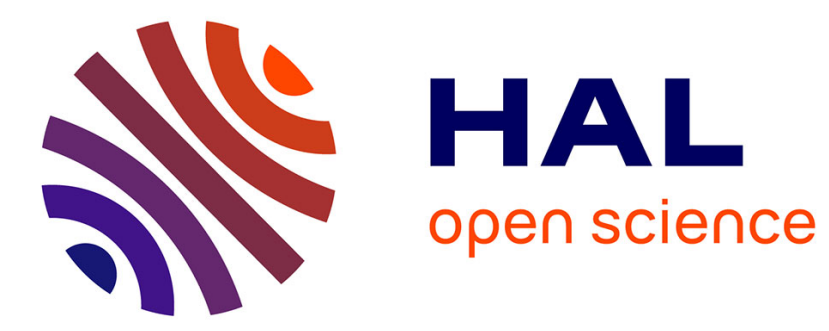

\title{
Experimental exposure to trace metals affects plumage bacterial community in the feral pigeon
}

Marion Chatelain, Adrien Frantz, Julien Gasparini, Sarah Leclaire

\section{To cite this version:}

Marion Chatelain, Adrien Frantz, Julien Gasparini, Sarah Leclaire. Experimental exposure to trace metals affects plumage bacterial community in the feral pigeon. 2016. hal-01274875

\section{HAL Id: hal-01274875 \\ https://hal.sorbonne-universite.fr/hal-01274875}

Preprint submitted on 16 Feb 2016

HAL is a multi-disciplinary open access archive for the deposit and dissemination of scientific research documents, whether they are published or not. The documents may come from teaching and research institutions in France or abroad, or from public or private research centers.
L'archive ouverte pluridisciplinaire HAL, est destinée au dépôt et à la diffusion de documents scientifiques de niveau recherche, publiés ou non, émanant des établissements d'enseignement et de recherche français ou étrangers, des laboratoires publics ou privés. 
Experimental exposure to trace metals affects plumage bacterial community in the feral pigeon

Chatelain $\mathrm{M}^{1^{*}}$, Frantz $\mathrm{A}^{1}$, Gasparini $\mathrm{J}^{1}$ and Leclaire $\mathrm{S}^{1,2}$

${ }^{1}$ Sorbonne Universités, UPMC Univ Paris 06, UPEC, Paris 7, CNRS, INRA, IRD, Institut d'Ecologie et des Sciences de 1'Environnement de Paris, F-75005, Paris, France

${ }^{2}$ Centre d'Ecologie Fonctionnelle et Evolutive, UMR 5175, CNRS, 1919 route de Mende, 34293 Montpellier, France

*Correspondingauthor: Marion Chatelain, Address : Université Pierre et Marie Curie 7 quai

St Bernard 75005 Paris France, E-mail : marion.chatelain@upmc.fr, Tel: +331442752 


\section{Abstract}

2 Bacteria are fundamental associates of animals, and recent studies have highlighted their

3 major role in host behaviour, immunity or reproductive investment. Thus, any environmental

4 factor modifying bacterial community may affect host fitness. In birds, trace metals emitted

5 by anthropogenic activities accumulate onto the plumage where they may alter bacterial 6 community and ultimately affect bird fitness. Although trace metals are current major

7 environmental issues in urban habitats, their effects on feather bacterial community have 8 never been investigated. Here, we supplemented feral pigeons (Columba livia), an 9 emblematic urban species, with zinc and/or lead in drinking and bath water. As expected, lead and zinc supplementations modified plumage bacterial communitycomposition. Zinc decreased bacterial load, while lead decreased bacterial richness andthe frequency of preening behaviour in birds, known to regulate feather bacteria. Our results demonstrate for the first time the effects of common urban trace metals on plumage bacterial community and shed light on one of the mechanisms by which trace metals can affect bird fitness. Further studies are now needed to investigate how this effectmodulates avianlife history traits known to depend on plumage bacterial community. 


\section{INTRODUCTION}

Bacteria successfully colonize numerous and various habitats, including animal body parts that are in direct contact with the surroundings such as skin, feathers or fur, and the digestive tract. The normal flora, also called the microbiota, lives in symbiosis with its host, fulfilling essential functions for host metabolism, such as cellulose degradation, vitamins synthesis(Hill 1997)and inhibition of pathogens proliferation (Olsson et al. 1992, Oh et al. 2006, Balcázar et al. 2007).Recent studies have also revealed that bacteria may have surprising effects such as shaping host behaviour and investment in reproduction (Ezenwa et al. 2012, Jacob et al. 2015). However, we have just made the first steps in discovering the diversity and functions of these bacterial ecosystems, and it is now necessary to evaluate the factors that regulate microbiota.

The microbiota is influenced by numerous interconnected factors, including host behaviour,genotype and physiology(Mueller et al. 2006, Frank et al. 2011, Rosenthal et al. 2011, Hildebrand et al. 2013, Leclaire et al. 2014a), as well as its environment(Dotterud et al. 2008, Burkholder et al. 2008, Ruiz-de-Castañeda et al. 2011).Trace metals emitted by anthropogenic activities have well-known detrimental effects on animals (Jarup 2003, Hsu et al. 2006, Berglund et al. 2007, Eeva et al. 2009) andare thus of major environmental concernsin most urban environments(Azimi et al. 2005, Scheifler et al. 2006, Roux and Marra 2007, Kekkonen et al. 2012). Some trace metals, such as lead, cadmium, zinc, copper, chrome and nickel, are known to have toxic effects onenvironmental microbial communities(Babich and Stotzky 1978, Giller et al. 1998). In contrast, although tracemetals can be naturally ingested or inhaled by animals, and deposited on integuments, their effects on animal microbiota have been poorly investigated (but seeHojberg et al. 2005, Vahjen et al. 2010, Breton et al. 2013, Liu et al. 2014). 
Plumage is a key point of interaction between birds and the microbial world, and, like other

47

48

49

50 integuments, is highly colonized by bacteria(Burtt Jr and Ichida 1999, Muza et al. 2000, Shawkey and Hill 2004, Whitaker et al. 2005). Although several studies have shown that keratinolytic bacteria can alter feather structure in vitro(Burtt Jr and Ichida 1999, Shawkey et al. 2007), the in vivo effects of feather bacteria on their host have been scarcely studied.A few correlative and experimental studies in captive and free-living birds have shown, however, that feather bacteria mayinfluence sexual signalization such as feather colouration or plumage condition (Shawkey et al. 2007, Gunderson et al. 2009, Kilgas et al. 2012, Leclaire et al. 2014b; but see Jacob et al. 2014), and affect bird immune system (Leclaire et al. 2015) and investment in reproduction (Jacob et al. 2015). Any change in feather microbiota is thus likely to have a strong impact on bird fitness. The plumage and the uropygial gland secretions spread onto it can accumulatemetals(Pilastro et al. 1993, Frantz et al. 2012), which can affectplumage bacterial community by direct contact. Ingested metalsalso circulate in the bloodstream and accumulate in organs and bones (Pattee 1984, Dauwe et al. 2002, Scheifler et al. 2006, Kekkonen et al. 2012, Reid et al. 2012), and may induce noxious (Redig et al. 1991, Snoeijs et al. 2004, Dauwe et al. 2005, Eeva et al. 2009)or beneficial (Mertz 1981, Prasad 1998)effects on bird physiology; therefore, metals can affect bird ability to regulate their microbiota(Piault et al. 2008, Moreno-Rueda 2010, Leclaire et al. 2014b). Whatever the exact underlying mechanisms, further studies are clearly needed to evaluate the effects of trace metals on feather bacteria.

The feral pigeon (Columba livia) is an emblematic urban bird living in high density populations, with potentially elevated plumage bacteria transmission between individuals (reviewed in Archie and Theis 2011). Mate choice is crucial for this species which mate for 
life (Johnston and Janiga 1995). In this species, bacterial load affects immunity(Leclaire et al. 2015), as well as feather condition and colouration(Leclaire et al. 2014b)which are two ofthe main criteria used in mate choice (Johnston and Janiga 1995). Consequently, trace metals, besides their direct effects on bird physiology, may further impact pigeon reproduction and fitness through their effects on plumage bacterial load and composition. Here we investigated the effects of an experimental exposure to lead and/or zinc on two traits that can affect each other: plumage bacteria composition and frequency of preening in the feral pigeon. Preening is a costly antimicrobial behaviour that can be directly influenced by feather bacterial load (Leclaire et al. 2014b)and bird health status (Piault et al. 2008, Moreno-Rueda 2010), which are both potentially affected by trace metals.

\section{MeTHODS}

\section{Subjects and housing}

Ninety six(48 males and 48 females)free-living adult feral pigeons (Columba livia) were caught during winter 2013 (February/March) in several pigeons' flocks within the Parisian agglomeration. Birds were all considered as adults because of their well-formed caruncle, the absence of juvenile plumage and the presence of iridescent neck feathers (Johnston and Janiga 1995). Pigeons werekeptin 8 outdooraviaries(3.10 $\mathrm{m} \times 2.00 \mathrm{~m} \times 2.40 \mathrm{~m})$ at the CEREEP field station (Centre d'Ecologie Expérimentale et Prédictive-Ecotron Ile-de-France, UMS 3194, Ecole Normale Supérieure, Saint-Pierre-lès-Nemours, France). They were evenly distributed among aviaries according to their flock, sexand plumage eumelanin level(see below) in such a way that there was no confounding effect between aviaries and these variables (i.e. no statistically significant link between aviary and flock: $\mathrm{Chi}^{2}=71.09, \mathrm{df}=70, \mathrm{P}=0.441$; sex: 6 
males and 6 females per aviary; or plumage eumelanin level: $\mathrm{F}_{1,80}=0.38, \mathrm{P}=0.537$ ). Birds were fed ad libitum with a mix of maize, wheat and peas and water was provided in a trough. The aviaries were enriched with a bowlofwater used forbathing and with branchesasperches. Birds were individually identified with a numbered plastic ring.Birds were genetically sexed following the protocol described byGriffiths et al. (1998). Before onset of treatment, birds were kept 2 to 7 weeks for acclimation. Alongside this experiment, we measured the effects of treatments (see below) on bird body mass condition, reproduction and immunity. At the end of the breeding season, all birds were released back to the wild at their site of capture.All experiments were carried out in strict accordance with the recommendations of the "European Convention for the Protection of vertebrate Animals used for Experimental and Other Scientific Purposes" and were conducted under the authorizations of the "Ministère de l'éducationnationale, de l'enseignementsupérieur et de la recherche" (authorization N_00093.02) and the "Direction Départementale des Services Vétérinaires de Seine etMarne" (authorization N_77-05).

\section{Measurement of plumage colouration}

At capture, birds were first categorised as eumelanic (grey to black pigmented) or pheomelanic (red pigmented) which define their melanin type. Then, eumelanic birds were individually photographed in order to measure their eumelanin level. Eumelanin level was calculated as the percentage of black on the wing surface (number of black pixels/number of white pixels $x$ 100) using the Gimp image retouching and editing software. This measure has been shown to be a reliable and repeatable estimation of melanin concentration in pigeons (Jacquin et al. 2011). In eumelanic pigeons, plumage eumelanin level ranged from 4.2 to 95.9\%. Because of the small amount of pheomelanic birds (14 over 96) the measure of a pheomelanin level was not relevant. 


\section{Treatments}

122 Two weeks before the onset of treatment, aviaries were divided into 4 metal-exposure treatments; this means that there were 2 aviaries per treatment with 12 pigeons each (24 pigeons in total per treatment). For each treatment, the two aviaries were purposely spatially separated from one another.Aviaries were in direct contact along a linear transect and numbered from 1 to 8 (lead (1), zinc (2), control (3), lead+zinc (4), lead (5), control (6), zinc(7), lead+zinc (8)). Side-by-side aviaries were separated by wire mesh.Treatments consisted of water supplemented with lead (lead group; 1ppm lead acetate; aviaries 1 and 5), zinc (zinc group; 10 ppm zinc sulphate; aviaries 2 and 7), lead and zinc (lead+zinc group; $1 \mathrm{ppm}$ lead acetate and 10ppm zinc sulphate; aviaries 4 and 8), or control(control group; tap water with no metal added; aviaries 3 and 6). We chose these concentrations based on both lead blood concentrations measured in urban birds (ranging from 0,053 to 0,264ppm; Roux and Marra 2007) and the gastrointestinal absorption rate of lead in zebra finches $(<10 \%)$ calculated from (Dauwe et al. 2002). Zinc concentrations were approximated using the zinc/lead concentration ratio in the environment and in bird feathers (on average, zinc was 10 times more concentrated than lead;Azimi et al. 2005, Frantz et al. 2012, Chatelain et al. 2014).Drinking troughs and baths were filled with the corresponding treated water every other day. Our supplementation treatments were validated by measuring lead and zinc concentrations in blood and feathers of the birds. Blood was sampled 10 weeks after the start of the experiment. Moreover, the fifth secondary remige of each bird was removed a first time and the regrowth feather was used for metal measurements. Both blood and feathers were digested using a previouslydescribed protocol (Chatelain et al. 2014) and lead and zinc concentrations were measured by mass spectrometry (ICP-MS) and by optic emission spectrometry (ICP-OES) respectively. Validity of analytical methods was checked by means 
of a standard biological reference material (TMDA-64.2. Environment Canada). Lead and zinc concentrations in blood were the highest among birds exposed to lead (lead and $l e a d+z i n c$ groups) and birds exposed to zinc (zinc and lead+zincgroups) respectively (Table 1). These results ensured that metals added to water were ingested by the birds. In feathers, while lead concentrations were significantly the highest among birds exposed to lead (lead and lead+zinc groups), the increase in zinc concentration among birds exposed to zinc (zinc and lead+zinc groups) was not significant (Table 1).Zinc and lead measured in the feathers were respectively 80 and 1.5 times less concentrated than the ones measured in feathers of urban pigeons (Nam et al. 2004, Adout et al. 2007, Hoff Brait and AntoniosiFilho 2011, Frantz et al. 2012, Chatelain et al. 2014), suggesting that our experimental exposure corresponded to the lower range of urban exposure.

\section{Measurement of plumage bacterial load}

Plumage bacterial load was measured 20 weeks after onset of treatment.4 hours after renewing the water of the bowls used for bathing, 10 birds (5 males and 5 females) were randomly sampled in each treatment. Each sampled birdwas caught with a net that hadbeen previously sprayed with 70\% ethanol. Then, a whole flora agar slide (Hygialim, 3026091, Plate Count Agar +triphenyltetrazoliumchloride+Neutralizing)was put flat against the back of the bird for 10 seconds. The slides were then incubated at $37^{\circ} \mathrm{C}$ for $24 \mathrm{~h}$.Feather bacterial load was expressed as the number of bacterial colonies per slide.

\section{Molecular analysis of plumage bacterial communities}

Fifteen weeks after the start of the experiment, 91 adults were caught with a net previously sprayed with $70 \%$ ethanol (n.b. 5 pigeons died for unknown reasonsbefore this measure, 2 from the zinc group, 2 from the lead+zinc group and 1 from the control group). After washing 
her hands with alcohol, the experimenter cut a clump (10 feathers on average) of back feathers with sterilized scissors and pliers, avoiding the outermost feathers. The feathers were immediately placed in sterile $2 \mathrm{ml}$ plastic tubes and stored at $-20^{\circ} \mathrm{C}$ until analysis.

173

We extracted DNA using the QiagenDNeasy® Blood and Tissue Kit and the standard protocol designed for the purification of total DNA from Gram-positive bacteria (Qiagen, Venlo, Netherlands; July 2006).

To characterize the bacterial communities present in each sample,we performed automated ribosomal intergenic spacer analyses(ARISA; Ranjard et al. 2000). This DNA fingerprinting method isbased on the amplification of the internal transcribed spacer (ITS)region lying between the $16 \mathrm{~S}$ and $23 \mathrm{~S}$ ribosomal RNA genes in theribosomal operon. The ITS region is extremely variable, in bothsequence and length, for different bacterial species. Therefore, theDNA amplification profile obtained with ARISA allows straightforwardestimation of bacterial diversity, avoiding biases inherent inclassical culture-based techniques (Ranjard et al. 2000).We amplified the ITS using the FAM (6-carboxyfluorescein)-labeled primer S-DBact-1522-b-S-20 (5'-[6FAM] TGCGGCTGGATCCCCTCCTT-3') and the unlabeled primer L-D-Bact-132-a-A-18 (5'-CCGGGTTTCCCCATTCGG-3')(Ranjard et al. 2000). We performed the PCR amplification in $10 \mu \mathrm{L}$ mixturescontaining $200 \mu \mathrm{M}$ each deoxynucleotide triphosphate, $0.20 \mu \mathrm{M}$ each primer, 1.25 units of PerfectTaq DNA polymerase, $1 \times$ PCR buffer(5 Prime, GmbH, Hamburg, Germany), and $1 \mu \mathrm{L}$ DNA extract, using the followingprotocol: initial denaturation at $94{ }^{\circ} \mathrm{C}$ for $3 \mathrm{~min}, 40$ cyclesconsisting of denaturation at $94{ }^{\circ} \mathrm{C}$ for $30 \mathrm{~s}$, annealing at $55{ }^{\circ} \mathrm{C}$ for $45 \mathrm{~s}$, elongation at $72{ }^{\circ} \mathrm{C}$ for $1 \mathrm{~min}$, and a final elongation at $72{ }^{\circ} \mathrm{C}$ for 10 min.We then mixed $1 \mu \mathrm{L}$ of the PCR products with $15 \mu \mathrm{L}$ of highly deionized formamide and $0.2 \mu \mathrm{L}$ of Genescan $1200 \mathrm{LIZ}$ size standard (Applied Biosystems, Foster City, CA). The mixtures were separated with a 24-capillary 3500XL DNA Analyzer (Applied Biosystems) using POP-7 polymer and the manufacturer's default electrophoresis 
run settings. Data analysis and genotyping were performed with GeneMapper software (Applied Biosystems). For each sample, the sequencer produced an ARISA profile in which each peak corresponds to 1 phylotype or operational taxonomic unit (OTU). In the various samples, the sequencer detected ITS fragments ranging in size from 300 to 950base pairs.

For each individual, we calculated bacterial richness as the number of different OTUs. Because the probability to detect an OTU is likely affected by the amount of feathers used for DNA extraction, feathers were dried overnight and weighted to the nearest mg after DNA extraction. We estimated bacterial community dissimilarities between individuals using Jaccard distance based on presence/absence of OTUs.

\section{Observations of preening behaviour}

An observer recorded a total of 95 independent behaviouralsessions of 5 minutes each. The observer remainedoutside the aviary and waited a few minutes before starting her observations not to influence bird behaviour.The observed birds were chosen randomly but the observer switchedto a newtreatment for each new session to have a similar number of observations forall treatments: 25 observations (corresponding to 21 different individuals) among the control group, 29 observations (24 individuals)among the lead group, 22 observations (20 individuals) among the zinc group and 19 observations (16 individuals) alongthe lead+zinc group. The behaviour recording was performed with the JWatcher software. We recorded the time birds spent preening;during this behaviour, the plumagemay be spread with preen secretions(Mardon et al. 2011), which have antimicrobial and antiparasite properties (e.g. in feral pigeons, house sparrows, eastern bluebirds and hoopoes; Moyer et al. 2003, Shawkey et al. 2007, Ruiz-Rodriguez et al. 2009, Waite et al. 2012, Czirják et al. 2013). Because preening is costly (Piault et al. 2008, Moreno-Rueda 2010), the time allocated to preening has been shown to beadjusted to bacterial load (Leclaire et al. 
2014b), and to reflect birds'health status. For instance, juvenile apapanes

221 (Himationesanguinea) experimentally infected with Plasmodium relictum spent less time preening (Yorinks and Atkinson 2000).

\section{Statistical analyses}

Statistical analyseswere performedusingR (R.3.0.2; R Development Core Team). Final models were retained based on their AIC.

To test the effects of metal exposure on the composition of bacterial communities, we performed a PERMANOVA with 5000 permutations (i.e. nonparametric multivariate analysis of variance, Adonis function, VEGAN package in R(Oksanen et al. 2007), based on Jaccard distance for OTU presence/absence data. Zinc exposure, lead exposure, sex and their interactions were included as explanatory variables. Because spatial proximity may influence bacterial communitysimilarity between individuals, we added the aviary as a covariate. Then, we ran similar analyses between each pair of treatments.Finally, we tested the differences of bacterial communities between aviaries among each metal treatment.

To investigate more precisely the effect of spatial proximity on bacterial communities' similarities, we compared a matrix of bacterial Jaccard distances between individuals to a matrix of spatial distances (scored as 0 for individuals inhabiting the same aviary, to 7 for the most distant individuals), considering a matrix of treatment membership (scored as 0 for individuals submitted to the treatment and 1 for individuals of different treatments) using partial mantel test with 5000 permutations.

We graphically represented similarities between individuals using a constrained redundancy analysis (RDA function in R) based on the Jaccard distance matrix. 
244 We also tested plumage bacterial richness using a generalized linear model for Poisson

245 distribution with zinc exposure, lead exposure, sex and their interactions as explanatory 246 variables, the weight of feathers used for the analysis as a covariate and aviary as random 247 effect.

249 To test the effects of metal exposure on plumage bacterial load, we performed Wilcoxon tests because our sample size was low ( $n=10$ per treatment). First, we tested the effects of zinc and theeffects of lead in two different tests; then, we performed Wilcoxon tests between each pair of treatments to test the effects of the interaction between zinc and lead exposure.

Finally, we investigated the amount of time birds allocated to preening by performing a generalized linear mixed model for Poisson distribution with zinc exposure, lead exposure, sex and their interactions as explicative variables and bird identity and aviary as random effects.

All the previously described models were performed on the totality of the birds, whatever their plumage colouration (i.e. eumelanic and pheomelanic birds). The same models were performed on eumelanic birds only (i.e. excluding pheomelanic pigeons). In these models, plumage eumelanin level and its interaction with the other considered parameters were added as explanatory variables.

RESUlts 
The composition of bacterial communities depended on the interaction between lead and zinc exposure $\left(\mathrm{F}_{1,82}=3.47, \mathrm{P}<0.001\right.$; Fig. 1$)$ and on aviaries $\left(\mathrm{F}_{1,82}=3.91, \mathrm{P}<0.001\right)$. Each pairwise test between metal exposureswas significant (Table 2). The composition of bacterial communities differed significantly between aviaries among each metal treatment but was less dissimilar among thelead group(zinc-exposure: $\mathrm{F}_{1,19}=3.48, \mathrm{P}<0.001$, lead-exposure: $\mathrm{F}_{1,21}=1.70, \mathrm{P}=0.018$, zinc and lead-exposure: $\mathrm{F}_{1,19}=4.48, \mathrm{P}<0.001$, control: $\left.\mathrm{F}_{1,20}=7.59, \mathrm{P}<0.001\right)$. Moreover, there was a highly significant positive correlation between bacterial distance and spatial distance (r=0.30, P<0.001; Fig. 2).

Plumage bacterial richness depended on the interaction between zinc and lead-exposure $\left(\mathrm{Chi}^{2}=9.09, \mathrm{df}=80, \mathrm{P}=0.003\right.$; Fig. 3): thelead group had lower bacterial richness than the control group $\left(\mathrm{Chi}^{2}=5.58, \mathrm{df}=42, \mathrm{P}=0.018\right)$ and the zinc + lead group $\left(\mathrm{Chi}^{2}=12.63, \mathrm{df}=41\right.$, $\mathrm{P}<0.001)$. Moreover, thelead + zinc group tended to have higher bacterial richness than thezinc group $\left(\mathrm{Chi}^{2}=3.63, \mathrm{df}=40, \mathrm{P}=0.057\right)$.

Plumage bacterial load was significantly lower amongbirds exposed to zinc (zinc and lead + zinc groups)than amongthe others (lead and control groups; $\mathrm{W}=280.5, \mathrm{P}=0.029 ;$ Fig.4). Although there was no significant difference between each pair of treatments $(\mathrm{P}>0.067)$, thezinc grouptended to have lower plumage bacterial loads than thecontrol group (W=29, $\mathrm{P}=0.072)$ and thelead $\operatorname{group}(\mathrm{W}=25, \mathrm{P}=0.067)$. Lead didnot significantly affect plumage bacterial load $(\mathrm{W}=181, \mathrm{P}=0.623)$.

Finally, the time birds spent preening depended on the interaction between zinc and leadexposure $\left(\mathrm{Chi}^{2}=3.97, \mathrm{df}=92, \mathrm{P}=0.04\right)$. We performed partial models to compare each pair of treatments. Although there was no significant difference between each pair of treatments 
( $>0.101)$, our results suggest that time spent preening was shorter among thelead group than among the other groups (control: $65.00 \pm 15.18 \mathrm{~s}$, lead: $34.21 \pm 9.69 \mathrm{~s}$, zinc: $53.86 \pm 13.79 \mathrm{~s}$, lead+zinc: $60.84 \pm 15.30 \mathrm{~s})$.

Sex and plumage eumelanin level were retained in none of the tested models.

\section{DISCUSSION}

As expected,the composition of plumage bacterial communityvaried with metal exposure. The exposure to lead alone appears to induce the strongest effect. Plumage bacterial composition was more similar amongst the two aviaries hosting birds exposed to lead only than expected if considering a spatial effect only. In addition, the plumage bacterial compositionsof birds exposed to lead only were the most distant from the communities of the other treatments.Moreover, birds of the lead grouphad reduced plumage bacterial richness compared to birds of the controlgroup. These results suggest that lead may select for leadtolerant plumage bacteria. To the best of our knowledge, our study is the first to showthat lead exposure has effects on plumage bacterial community. It is consistent with a previous study showing that lead alters the intestinal microbiome of mice (Breton et al. 2013).Moreover, birds of the lead grouptended to preen less frequently than birds of the control group. Lead exposure decreases bird immunity (unpublished results) and reproductive success (but there is no effect of metal exposure on bird breeding success; Chatelain et al. in press). Lead, by decreasing bird condition,may affectbird ability to preen, a costly behaviour that helps to regulate feather microbiota(Piault et al. 2008, Moreno-Rueda 2010, Leclaire et al. 2014b). Because preening is adjusted to feather bacterial load(Leclaire et al. 2014b), the change in 
preening frequency observed in our study may also non-exclusively result from the change in feather bacterial community caused by trace metal exposure. Whatever the mechanism underlyingthe differences in preening frequency,the tendency of lead to reduce bird control on its plumage bacterial communitymay change the dominant status of bacteria species and therefore induce the proliferation of species that were previously sensitive to preen secretions. High-throughput DNA sequencing would help identifying lead-tolerant bacteria species and therefore inferring their potential pathogenicity and propensity to degrade feathers. More analyses should also be conducted to identify the proximal mechanisms involved in lead toxicity. For instance, in vitro exposure of feathers to these metals would allow us to disentanglethe direct and indirect effects that may induce these metals.

Like lead exposure, zinc exposure had toxic effects on the plumage bacterial community with birds exposed to zinc exhibiting lower bacterial load than control birds. Similarly, high doses of zinc decrease bacterial load and change bacterial community in the gastrointestinal tract of piglets (Hojberg et al. 2005, Vahjen et al. 2010), and inhibit bacterial growth in sludge and sediment (Cabrero et al. 1998, Vega-López et al. 2007).Zinc is known to be essential to several metabolic functions of bacteria (Sugarman 1983). At high concentrations, zinc can however reduce protein and ATP content, interact with nucleic acids and enzyme active sites, decrease membrane health and eventually lead to cell necrosis (Martinez-Tabche and Gutierr 2000, Vega-López et al. 2007). Although the concentration of zinc we used is within the natural range found in cities, it maybe high enough to negatively affect feather bacteria and to

339 decreasebacterial load. Zinc may also affect feather bacterial loadindirectly through its immunostimulating effect (Smith 2003). In feral pigeons, zinc has a positive effect on the production of specific antibodies (unpublished data), and might,therefore, increase the bactericidal capacity of uropygial secretions. 
344 Bacterial community composition, bacterial richness and the time birds spent preening 345 depended on the interaction between lead and zinc exposure. More precisely, the toxic effects 346 of lead exposure was not detectedin birds exposed to both lead and zinc, suggesting that zinc 347 may compensate lead toxicity. Zinc is known to reduce the absorption and retention of 348 ingested lead (Cerklewski and Forbes 1976, El-Gazzar et al. 1978, Prasanthi et al. 2010), which may therefore reduce the negative effects of lead on bird condition. In addition, the negative effect of zinc exposure on bacterial load would be higher in birds exposed to zinc

351 only than in birds exposed to both lead and zinc, suggesting again an interaction between lead and zinc exposure.

Our results showed a strong effect of spatial proximity on bird plumage bacterial community, with birds in closer aviaries showing more similar bacterial communities. In accordance with other studies (Bisson et al. 2007, 2009, Saag et al. 2011), they point out the relatively small spatial scale transmission of plumage bacteria. While bacteria are likely transmitted through close contacts(Kulkarni and Heeb 2007) and reciprocal delousing, some bacteria may be able to survive on non-feather substrates and, therefore, be transmitted through bathwater, perches, soil and the grids separating the aviaries(Bisson et al. 2007). Because pigeons live in high density but have limited movements within their local environment (Frantz et al. 2012), the plumage bacterial communityof wild pigeons may, therefore,greatly vary between populations, which may lead to local coevolution and co-adaptation between the host and its bacterial community.The strong effect of spatial proximity on plumage bacterial community detected in our study may have decreased and increased bacterial community similarities between and within aviaries respectively; ideally, future studies should increase the number of replicates (aviaries) or house pigeons in individual and spatially distant cages. 
369 Our experimental exposure of feral pigeons to naturallyoccurring concentrations of lead and/or zinc highlights, for the first time, the effects of some trace metals commonly encountered in urban areas on plumage bacterial community. The birds used in our study were captured in Paris, andhad therefore been previously exposed to trace metals in their natural urban habitat. Consequently, plumage bacterial communities at the start of the experiment might havealready been shaped by pastmetal exposure. Because there was no significant correlation between bird capture site (i.e. pigeon flock) and aviary, the potential initial differences in bacterial community between the birds would, however, have reduced the power of our analysis, and the significant differences between treatments observed in our study are therefore conservative.

Although our knowledge on plumage bacterial community composition and function is scarce, feather bacteria seem to play a role in bird immunity, reproduction and feather colouration and condition (Clayton 1999, Shawkey et al. 2007, Gunderson et al. 2009, Leclaire et al. 2014, 2015, Jacob et al. 2015 but see Jacob et al. 2014). Through their effects on plumage bacteria, trace metals may, for instance,affect thermoregulation and visual signalspotentially involved in dominant status assessment and mate choice (Wolf 2000, Hill and McGraw 2006). Future studies should now investigate if and how the changes in plumage bacterial communities induced by trace metals affect bird fitness.

\section{ACKNOWLEDGMENTS}

We thank the "Mairie de Paris" (Thomas Charachon) for allowing the capture of birds and the Centre de RechercheenEcologieExpérimentale et Prédictive (CEREEP) which provided 
393 logistic support for the field work of this study. We are very thankful to T. Gayet, S. Pollet, S.

394 Hasnaoui, F. Lorente, S. Perret and B. Decencière for their help all along the field work.

395 Molecular analyses were partly performed at the technical facilities of the labexCeMEB and

396 were funded by an "ANR PDOC" grant (to SL) (No. ANR-13-PDOC-0002). 


\section{REFERENCES}

Adout, A., Hawlena, D., Maman, R., Paz-Tal, O. and Karpas, Z. 2007. Determination of trace elements in pigeon and raven feathers by ICPMS. - Int. J. Mass Spectrom. 267: 109116.

Agusa, T., Matsumoto, T., Ikemoto, T., Anan, Y., Kubota, R., Yasunaga, G., Kunito, T., Tanabe, S., Ogi, H. and Shibata, Y. 2005. Body distribution of trace elements in blacktailed gulls from Rishiri Island, Japan: Age-dependent accumulation and transfer to feathers and eggs. - Environ. Toxicol. Chem. 24: 2107-2120.

Archie, E. A. and Theis, K. R. 2011. Animal behaviour meets microbial ecology. - Anim. Behav. 82: 425-436.

Azimi, S., Rocher, V., Muller, M., Moilleron, R. and Thevenot, D. R. 2005. Sources, distribution and variability of hydrocarbons and metals in atmospheric deposition in an urban area (Paris, France). - Sci. Total Environ. 337: 223-239.

Babich, H. and Stotzky, G. 1978. Toxicity of zinc to fungi, bacteria, and coliphages: influence of chloride ions. - Appl. Environ. Microbiol. 36: 906-914.

Balcázar, J. L., Vendrell, D., de Blas, I., Ruiz-Zarzuela, I., Gironés, O. and Múzquiz, J. L. 2007. In vitro competitive adhesion and production of antagonistic compounds by lactic acid bacteria against fish pathogens. - Vet. Microbiol. 122: 373-380.

Berglund, A., Sturve, J., Forlin, L. and Nyholm, N. 2007. Oxidative stress in pied flycatcher (Ficedulahypoleuca) nestlings from metal contaminated environments in northern Sweden. - Environ. Res. 105: 330-339. 
Bisson, I.-A., Marra, P. P., Burtt, E. H., Sikaroodi, M. and Gillevet, P. M. 2007. A molecular comparison of plumage and soil bacteria across biogeographic, ecological, and taxonomic scales. - Microb. Ecol. 54: 65-81.

Bisson, I.-A., Marra, P. P., Burtt Jr, E. H., Sikaroodi, M. and Gillevet, P. M. 2009. Variation in Plumage Microbiota Depends on Season and Migration. - Microb. Ecol. 58: 212220.

Breton, J., Massart, S., Vandamme, P., De Brandt, E., Pot, B. and Foligné, B. 2013. Ecotoxicology inside the gut: impact of heavy metals on the mouse microbiome. BMC Pharmacol. Toxicol. 14: 62.

Burkholder, K. M., Thompson, K. L., Einstein, M. E., Applegate, T. J. and Patterson, J. A. 2008. Influence of stressors on normal intestinal microbiota, intestinal morphology, and susceptibility toSalmonella enteritidiscolonization in broilers. - Poult. Sci. 87: $1734-1741$.

Burtt Jr, E. H. and Ichida, J. M. 1999. Occurence of feather-degrading bacilli in the plumage of birds. - The Auk 116: 364-372.

Cabrero, A., Fernandez, S., Mirada, F. and Garcia, J. 1998. Effects of copper and zinc on the activated sludge bacteria growth kinetics. - Water Res. 32: 1355-1362.

Caro, S. P., Balthazart, J. and Bonadonna, F. 2015. The perfume of reproduction in birds: Chemosignaling in avian social life. - Horm. Behav. 68: 25-42.

Cerklewski, F. L. and Forbes, R. M. 1976. Influence of dietary zinc on lead toxicity in the rat. - J. Nutr. 106: 689-696. 
Chatelain, M., Gasparini, J., Jacquin, L. and Frantz, A. 2014. The adaptive function of melanin-based plumage colouration to trace metals. - Biol. Lett. 10: 2014016420140164.

Chatelain, M., Gasparini, J. and Frantz, A. In press. Do trace metals select for darker birds in urban areas? An experimental exposure to lead and zinc. - Glob. Change Biol.

Clayton, D. H. 1999. Feather-busting bacteria. - The Auk 116: 302-304.

Cosson, R. P., Amiard, J.-C. and Amiard-Triquet, C. 1988. Trace elements in little egrets and flamingos of Camargue, France. - Ecotoxicol. Environ. Saf. 15: 107-116.

Czirják, G. Á., Pap, P. L., Vágási, C. I., Giraudeau, M., Mureşan, C., Mirleau, P. and Heeb, P. 2013. Preen gland removal increases plumage bacterial load but not that of featherdegrading bacteria. - Naturwissenschaften 100: 145-151.

Dauwe, T., Janssens, E., Pinxten, R. and Eens, M. 2005. The reproductive success and quality of blue tits (Paruscaeruleus) in a heavy metal pollution gradient. - Environ. Pollut. 136: $243-251$.

Dauwe, L. Bervoets, R. Blust, M. Ee, T. 2002. Tissue levels of lead in experimentally exposed zebra finches (Taeniopygiaguttata) with particular attention on the use of feathers as biomonitors. - Arch. Environ. Contam. Toxicol. 42: 88-92.

Dotterud, L. K. are, Wilsgaard, T., Vorland, L. H. and Falk, E. S. 2008. The effect of UVB radiation on skin microbiota in patients with atopic dermatitis and healthy controls. Int. J. Circumpolar Health in press. 
Eeva, T., Ahola, M. and Lehikoinen, E. 2009. Breeding performance of blue tits (Cyanistescaeruleus) and great tits (Parus major) in a heavy metal polluted area. Environ. Pollut. 157: 3126-3131.

El-Gazzar, R. M., Finelli, V. N., Boiano, J. and Petering, H. G. 1978. Influence of dietary zinc on lead toxicity in rats. - Toxicol. Lett. 1: 227-234.

Ezenwa, V. O., Gerardo, N. M., Inouye, D. W., Medina, M. and Xavier, J. B. 2012. Animal behaviour and the microbiome. - Science 338: 198-199.

Frank, D. N., Robertson, C. E., Hamm, C. M., Kpadeh, Z., Zhang, T., Chen, H., Zhu, W., Sartor, R. B., Boedeker, E. C., Harpaz, N., Pace, N. R. and Li, E. 2011. Disease phenotype and genotype are associated with shifts in intestinal-associated microbiota in inflammatory bowel diseases: - Inflamm. Bowel Dis. 17: 179-184.

Frantz, A., Pottier, M.-A., Karimi, B., Corbel, H., Aubry, E., Haussy, C., Gasparini, J. and Castrec-Rouelle, M. 2012. Contrasting levels of heavy metals in the feathers of urban pigeons from close habitats suggest limited movements at a restricted scale. - Environ. Pollut. 168: 23-28.

Giller, K. E., Witter, E. and Mcgrath, S. P. 1998. Toxicity of heavy metals to microorganisms and microbial processes in agricultural soils: a review. - Soil Biol. Biochem. 30: $1389-1414$.

Griffiths, R., Double, M. C., Orr, K. and Dawson, R. J. G. 1998. A DNA test to sex most birds. - Mol. Ecol. 7: 1071-1075.

Gulson, B., Mizon, K. J., Korsch, M. J., Howarth, D., Phillips, A. and Hall, J. 1996. Impact on blood lead in children and adults following relocation from their source of exposure 
and contribution of skeletal tissue to blood lead. - Bull. Environ. Contam. Toxicol. 56: $543-550$.

Gunderson, A. R., Forsyth, M. H. and Swaddle, J. P. 2009. Evidence that plumage bacteria influence feather colouration and body condition of eastern bluebirds Sialiasialis. - J. Avian Biol. 40: 440-447.

Hildebrand, F., Nguyen, T. L., Brinkman, B., Yunta, R. G., Cauwe, B., Vandenabeele, P., Liston, A. and Raes, J. 2013. Inflammation-associated enterotypes, host genotype, cage and inter-individual effects drive gut microbiota variation in common laboratory mice. - Genome Biol 14: R4.

Hill, M. 1997. Intestinal flora and endogenous vitamin synthesis. - Eur. J. Cancer Prev.6: S43S45.

Hill, G. E. and McGraw, K. J. 2006. Bird colouration. - Harvard University Press.

Hoff Brait, C. H. and AntoniosiFilho, N. R. 2011. Use of feathers of feral pigeons (Columba livia) as a technique for metal quantification and environmental monitoring. - Environ. Monit. Assess. 179: 457-467.

Hojberg, O., Canibe, N., Poulsen, H. D., Hedemann, M. S. and Jensen, B. B. 2005. Influence of dietary zinc oxide and copper sulfate on the gastrointestinal ecosystem in newly weaned piglets. - Appl. Environ. Microbiol. 71: 2267-2277.

Hsu, M. J., Selvaraj, K. and Agoramoorthy, G. 2006. Taiwan's industrial heavy metal pollution threatens terrestrial biota. - Environ. Pollut. 143: 327-334.

Jacob, S., Colmas, L., Parthuisot, N. and Heeb, P. 2014. Do feather-degrading bacteria actually degrade feather colour? No significant effects of plumage microbiome 
modifications on feather colouration in wild great tits. - Naturwissenschaften 101: 929-938.

Jacob, S., Parthuisot, N., Vallat, A., Ramon-Portugal, F., Helfenstein, F. and Heeb, P. 2015. Microbiome affects egg carotenoid investment, nestling development and adult oxidative costs of reproduction in great tits. - Funct. Ecol 8 : 1048-1058.

Jacquin, L., Lenouvel, P., Haussy, C., Ducatez, S. and Gasparini, J. 2011. Melanin-based colouration is related to parasite intensity and cellular immune response in an urban free living bird: the feral pigeon Columba livia. - J. Avian Biol. 42: 11-15.

Jarup, L. 2003. Hazards of heavy metal contamination. - Br. Med. Bull. 68: 167-182.

Johnston, R. and Janiga, M. 1995. Feral pigeons. - Oxford University Press.

Kekkonen, J., Hanski, I. K., Väisänen, R. A. and Brommer, J. E. 2012. Levels of heavy metals in house sparrows(Passer domesticus) from urban and rural habitats of southern Finland. - OrnisFenn. 89: 91-98.

Kilgas, P., Saag, P., Mägi, M., Edenberg, M., Tilgar, V. and Mänd, R. 2012. Variation in assemblages of feather bacteria in relation to plumage color in female great tits. - The Condor 114: 606-611.

Kim, E. Y., Goto, R., Tanabe, S., Tanaka, H. and Tatsukawa, R. 1998. Distribution of 14 elements in tissues and organs of oceanic seabirds. - Arch. Environ. Contam. Toxicol. 35: 638-645.

Kulkarni, S. and Heeb, P. 2007. Social and sexual behaviours aid transmission of bacteria in birds. - Behav. Processes 74: 88-92. 
Leclaire, S., Nielsen, J. F. and Drea, C. M. 2014a. Bacterial communities in meerkat anal scent secretions vary with host sex, age, and group membership. - Behav. Ecol. 25: 996-1004.

Leclaire, S., Pierret, P., Chatelain, M. and Gasparini, J. 2014b. Feather bacterial load affects plumage condition, iridescent colour, and investment in preening in pigeons. - Behav. Ecol. 25: 1192-1198.

Leclaire, S., Czirjak, G., Hammouda, A. and Gasparini, J. 2015. Feather bacterial load shapes the trade-off between preening and immunity in pigeons. BMC Evolutionary Biology 15: 60 .

Liu, Y., Li, Y., Liu, K. and Shen, J. 2014. Exposing to cadmium stress cause profound toxic effect on microbiota of the mice intestinal tract. - PLoS ONE 9: e85323.

Mardon, J., Saunders, S. M. and Bonadonna, F. 2011. From preen secretions to plumage: the chemical trajectory of blue petrels' Halobaenacaerulea social scent. - J. Avian Biol. 42: $29-38$.

Martinez-Tabche, L. and Gutierr, I. 2000. Toxic effects of zinc from trout farm sediments on ATP, protein, and hemoglobin concentrations of Limnodrilushoffmeisteri. - J. Toxicol. Environ. Health A 59: 575-583.

Mertz, W. 1981. The essential trace elements. - Science 213: 1332-1338.

Moreno-Rueda, G. 2010. Uropygial gland size correlates with feather holes, body condition and wingbar size in the house sparrow Passer domesticus. - J. Avian Biol. 41: 229236. 
Moyer, B. R., Rock, A. N. and Clayton, D. H. 2003. Experimental test of the importance of preen oil in rock doves (Columba livia). - The Auk 120: 490.

Mueller, S., Saunier, K., Hanisch, C., Norin, E., Alm, L., Midtvedt, T., Cresci, A., Silvi, S., Orpianesi, C., Verdenelli, M. C., Clavel, T., Koebnick, C., Zunft, H.-J. F., Dore, J. and Blaut, M. 2006. Differences in fecal microbiota in different european study populations in relation to age, gender, and country: a cross-sectional study. - Appl. Environ. Microbiol. 72: 1027-1033.

Muza, M. M., Burtt, E. H. and Ichida, J. M. 2000. Distribution of bacteria on feathers of some eastern North American birds. - Wilson Bull. 112: 432-435.

Nam, D.-H., Lee, D.-P. and Koo, T.-H. 2004. Monitoring for lead pollution using feathers of feral pigeons (Columba livia) from Korea. - Environ. Monit. Assess. 95: 13-22.

Oh, S., Kim, S.-H., Ko, Y., Sim, J.-H., Kim, K. S., Lee, S.-H., Park, S. and Kim, Y. J. 2006. Effect of bacteriocin produced by Lactococcus sp. HY 449 on skin-inflammatory bacteria. - Food Chem. Toxicol. 44: 552-559.

Oksanen, J., Kindt, R., Legendre, P., O’Hara, B., Stevens, M., Oksanen, M. and Suggests, M. 2007. The vegan package. Community ecology package 661-637.

Olsson, J. C., Westerdahl, A., Conway, P. L. and Kjelleberg, S. 1992. Intestinal colonization potential of turbot (Scophthalmus maximus)-and dab (Limandalimanda)-associated bacteria with inhibitory effects against Vibrio anguillarum. - Appl. Environ. Microbiol. 58: 551-556.

Pattee, O. H. 1984. Eggshell thickness and reproduction in American kestrels exposed to chronic dietary lead. - Arch. Environ. Contam. Toxicol. 13: 29-34. 
Piault, R., Gasparini, J., Bize, P., Paulet, M., McGraw, K. J. and Roulin, A. 2008. Experimental support for the makeup hypothesis in nestling tawny owls (Strixaluco). Behav. Ecol. 19: 703-709.

Pilastro, A., Congiu, L., Tallandini, L. and Turchetto, M. 1993. The use of bird feathers for the monitoring of cadmium pollution. - Arch. Environ. Contam. Toxicol. 24: 355-358.

Prasad, A. S. 1998. Zinc and immunity. - Mol. Cell. Biochem. 188: 63-69.

Prasanthi, R. P. J., Devi, C. B., Basha, D. C., Reddy, N. S. and Reddy, G. R. 2010. Calcium and zinc supplementation protects lead $(\mathrm{Pb})$-induced perturbations in antioxidant enzymes and lipid peroxidation in developing mouse brain. - Int. J. Dev. Neurosci. 28: $161-167$.

Ranjard, L., Brothier, E. and Nazaret, S. 2000. Sequencing bands of ribosomal intergenic spacer analysis fingerprints for characterization and microscale distribution of soil bacterium populations responding to mercury spiking. - Appl. Environ. Microbiol. 66: $5334-5339$.

Redig, P. T., Lawler, E. M., Schwartz, S., Dunnette, J. L., Stephenson, B. and Duke, G. E. 1991. Effects of chronic exposure to sublethal concentrations of lead acetate on heme synthesis and immune function in red-tailed hawks. - Arch. Environ. Contam. Toxicol. 21: $72-77$.

Reid, C., McInnes, K., McLelland, J. M. and Gartrell, B. D. 2012. Anthropogenic lead (Pb) exposure in populations of a wild parrot (kea Nestor notabilis). - N. Z. J. Ecol. 36: 56. 
Rosenthal, M., Goldberg, D., Aiello, A., Larson, E. and Foxman, B. 2011. Skin microbiota: Microbial community structure and its potential association with health and disease. Infect. Genet. Evol. 11: 839-848.

Roux, K. E. and Marra, P. P. 2007. The presence and impact of environmental lead in passerine birds along an urban to rural land use gradient. - Arch. Environ. Contam. Toxicol. 53: 261-268.

Ruiz-de-Castañeda, R., Vela, A. I., Lobato, E., Briones, V. and Moreno, J. 2011. Bacterial loads on eggshells of the pied flycatcher: environmental and maternal factors. - The Condor 113: 200-208.

Ruiz-Rodriguez, M., Valdivia, E., Soler, J. J., Martin-Vivaldi, M., Martin-Platero, A. M. and Martinez-Bueno, M. 2009. Symbiotic bacteria living in the hoopoe's uropygial gland prevent feather degradation. - J. Exp. Biol. 212: 3621-3626.

Saag, P., Tilgar, V., Mänd, R., Kilgas, P. and Mägi, M. 2011. Plumage bacterial assemblages in a breeding wild passerine: relationships with ecological factors and body condition. - Microb. Ecol. 61: 740-749.

Scheifler, R., Cœurdassier, M., Morilhat, C., Bernard, N., Faivre, B., Flicoteaux, P., Giraudoux, P., Noël, M., Piotte, P., Rieffel, D., de Vaufleury, A. and Badot, P.-M. 2006. Lead concentrations in feathers and blood of common blackbirds (Turdusmerula) and in earthworms inhabiting unpolluted and moderately polluted urban areas. - Sci. Total Environ. 371: 197-205.

Shawkey, M. D. and Hill, G. E. 2004. Feathers at a fine scale. - The Auk 121: 652. 
Shawkey, M. D., Pillai, S. R. and Hill, G. E. 2003. Chemical warfare? Effects of uropygial oil on feather-degrading bacteria. - J. Avian Biol. 34: 345-349.

Shawkey, M. D., Pillai, S. R., Hill, G. E., Siefferman, L. M. and Roberts, S. R. 2007. Bacteria as an agent for change in structural plumage colour: correlational and experimental evidence. - Am. Nat. 169: S112-S121.

Smith, M. O. 2003. Effects of different levels of zinc on the performance and immunocompetence of broilers under heat stress. - Poult. Sci. 82: 1580-1588.

Snoeijs, T., Dauwe, T., Pinxten, R., Vandesande, F. and Eens, M. 2004. Heavy metal exposure affects the humoral immune response in a free-living small songbird, the great tit (Parus major). - Arch. Environ. Contam. Toxicol. 46: 399-404.

Sugarman, B. 1983. Zinc and Infection. - Clin. Infect. Dis. 5: 137-147.

Vahjen, W., Pieper, R. and Zentek, J. 2010. Bar-Coded Pyrosequencing of 16S rRNAgene amplicons reveals changes in ilealporcine bacterial communities due to high dietary zinc intake. - Appl. Environ. Microbiol. 76: 6689-6691.

Vega-López, A., Amora-Lazcano, E., López-López, E., Terrón, O. and Proal-Nájera, J. B. 2007. Toxic effects of zinc on anaerobic microbiota from Zimapán Reservoir (Mexico). - Anaerobe 13: 65-73.

Waite, J. L., Henry, A. R. and Clayton, D. H. 2012. How effective is preening against mobile ectoparasites? An experimental test with pigeons and hippoboscid flies. - Int. J. Parasitol. 42: 463-467.

Whitaker, J. M., Cristol, D. A. and Forsyth, M. H. 2005. Prevalence and genetic diversity of Bacillus licheniformis in avian plumage. - J. Field Ornithol. 76: 264-270. 
631 Wolf, B. O. 2000. The role of the plumage in heat transfer processes of birds. - Integr. Comp.

632 Biol. 40: 575-584.

633 Yorinks, N. and Atkinson, C. T. 2000. Effects of malaria on activity budgets of 634 experimentally infected juvenile apapane (Himationesanguinea). - The Auk 117: 731. 
637 Fig. 1 Constrained redundancy analysis (RDA function in R) on bacterial community 638 dissimilarities (estimated by Jaccard distances) between lead, zinc, lead and zinc and 639 controlgroups. Both aviaries of a same treatment are distinguished using either filled or empty 640 circles.

641

642 Fig. 2 Mean \pm SE plumage bacterial community dissimilarities(estimated by Jaccard distance)

643 in dyads of pigeons according to the spatial distance between them $(0$ means that the 644 individuals belonged to the same aviary, 1 means that they were in side-by-side aviaries, 2 645 means that 1 aviary was between them, etc.).

646

647 Fig. 3 Mean \pm SE plumage bacterial richness (number of different OTUs) according to metal 648 exposure. $a$ and $b$ were significantly different $(p$-value $<0.05)$ while $a b$ was not different from 649 a or from $b$.

650

651 Fig. 4 Mean \pm SE plumage bacterial load (number of bacterial colonies per slide) according to 652 metal exposure. Tests were performed for each pair of treatment. $a$ and $b$ tended to be 653 different (p-value<0.072) while ab was not different from a or from b. 
Table 1. Lead blood and feathers concentrations (mean \pm se, ppb) in lead-exposed and lead non-exposed birds, zinc blood and feathers concentrations (mean \pm se, $\mathrm{ppm}$ ) in zinc-exposed and zinc non-exposed birds and ANOVAs with lead or zinc concentrations in blood or feathers as dependent variable and zinc or lead exposure as explanatory variable.

\begin{tabular}{|c|c|c|c|c|c|}
\hline & & Lead exposed & Lead non-exposed & $\mathrm{F}$ & $\mathrm{P}$ \\
\hline \multirow{3}{*}{ Lead } & Blood & $55.49 \pm 6.54$ & $35.73 \pm 6.77$ & 4.47 & 0.040 \\
\hline & Feathers & $402.31 \pm 35.68$ & $255.81 \pm 49.75$ & 19.61 & $<0.001$ \\
\hline & & Zinc exposed & Zinc non-exposed & $\mathrm{F}$ & $\mathrm{P}$ \\
\hline \multirow{2}{*}{ Zinc } & Blood & $4.69 \pm 0.15$ & $4.20 \pm 0.18$ & 5.52 & 0.022 \\
\hline & Feathers & $96.62 \pm 2.15$ & $92.31 \pm 2.25$ & 2.13 & 0.149 \\
\hline
\end{tabular}


Table 2. PERMANOVAs with 5000 permutations based on Jaccard distance for OTU presence/absence data with the metal exposure as the explicative variable. Bacterial communities' similarities were compared between each pair of metal treatment.

\begin{tabular}{cccc}
\cline { 2 - 3 } & Control & Zinc-exposure & Lead-exposure \\
\hline Zinc-exposure & $\mathrm{F}_{1,40}=2.74, \mathrm{P}=0.002$ & - & - \\
Lead-exposure & $\mathrm{F}_{1,42}=3.44, \mathrm{P}<0.001$ & $\mathrm{~F}_{1,41}=3.16, \mathrm{P}<0.001$ & - \\
Zinc and lead- & & & \\
exposure & $\mathrm{F}_{1,40}=4.40, \mathrm{P}<0.001$ & $\mathrm{~F}_{1,39}=2.10, \mathrm{P}=0.006$ & $\mathrm{~F}_{1,41}=5.13, \mathrm{P}<0.001$ \\
& & & \\
\hline
\end{tabular}


Fig. 1

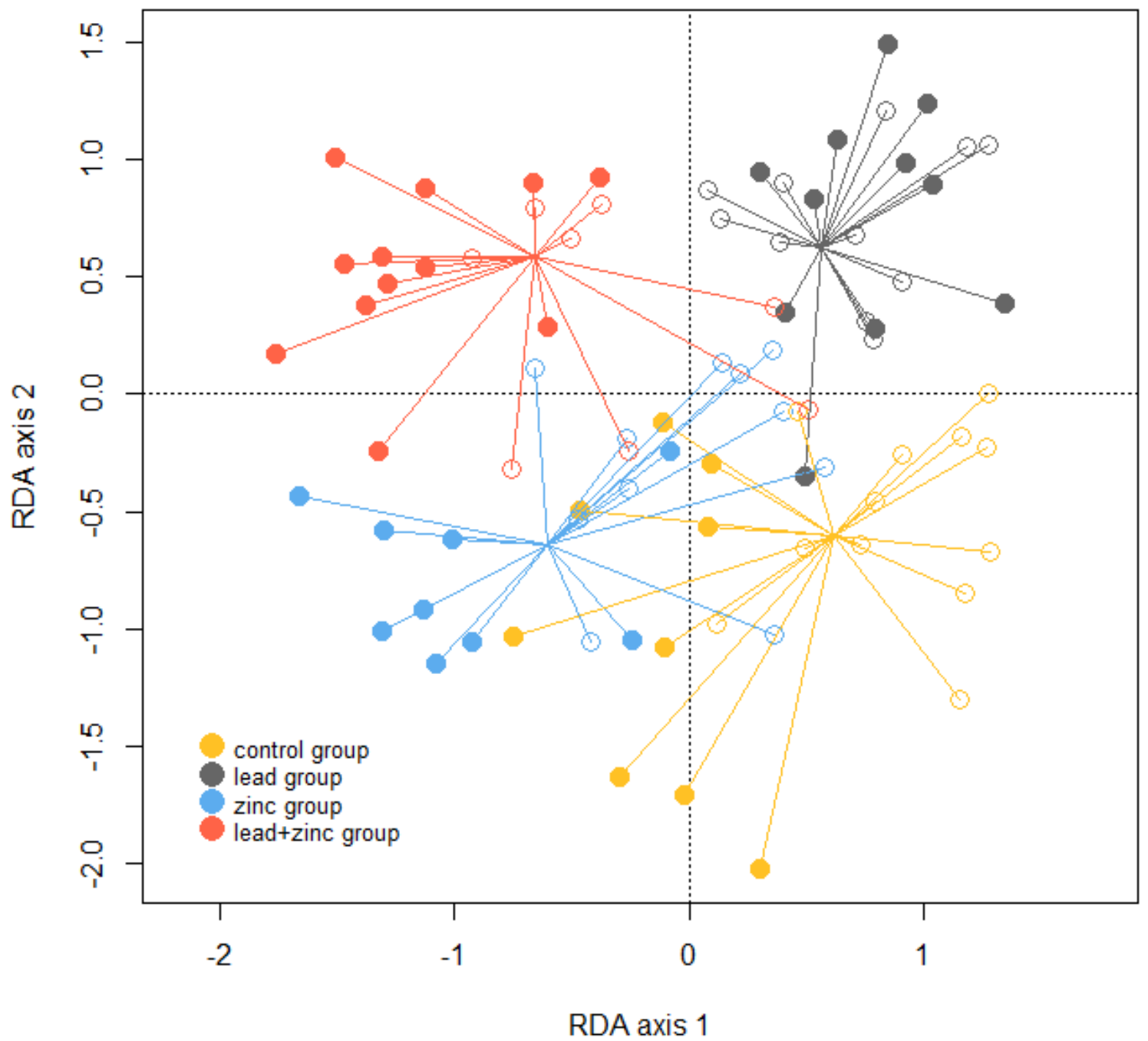


Fig. 2

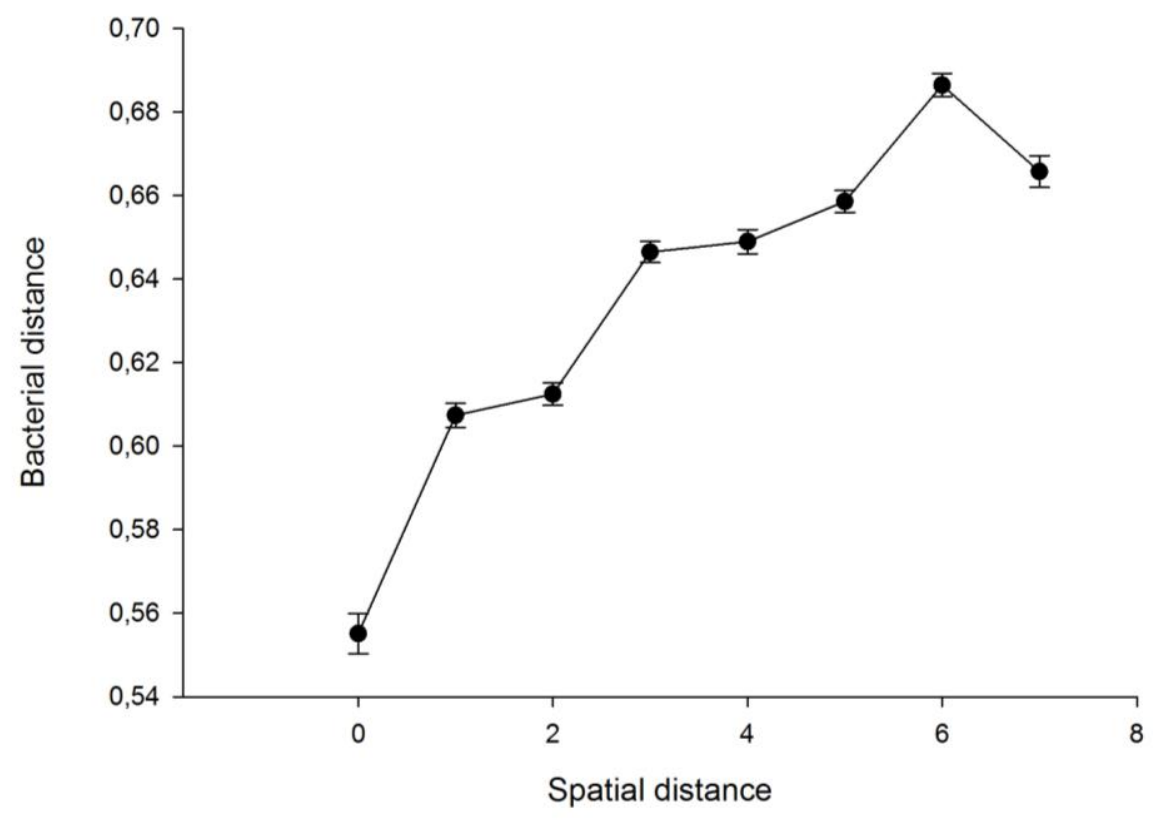


Fig. 3

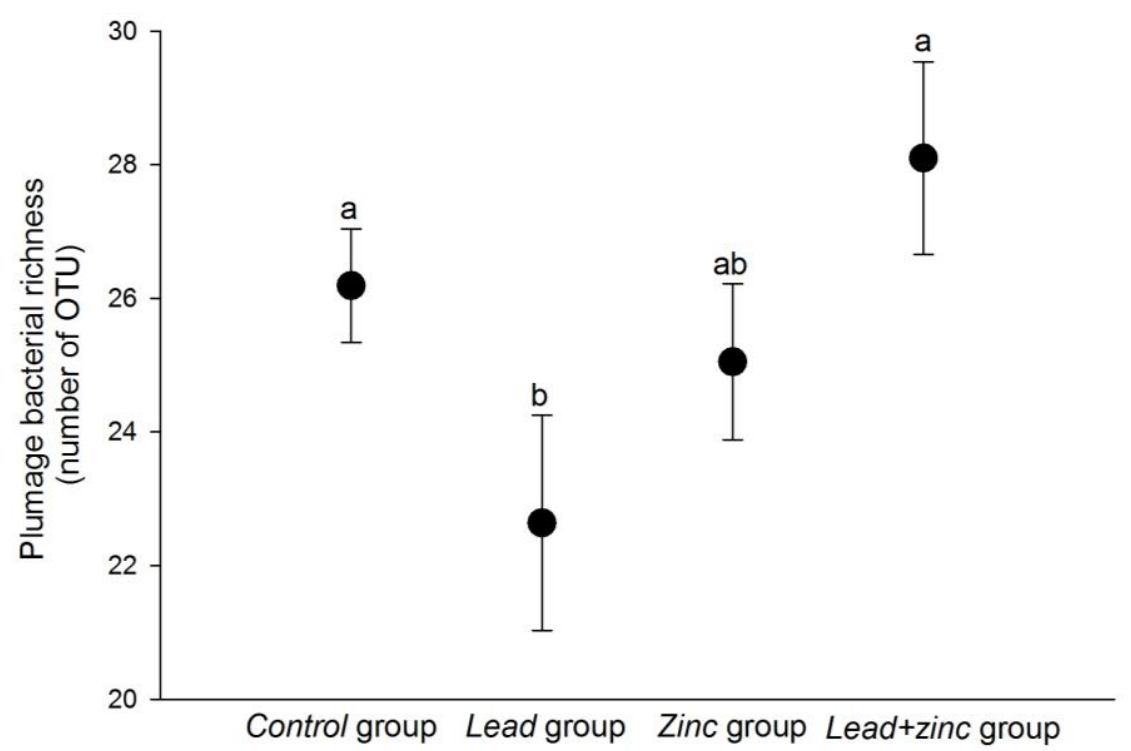


Fig. 4

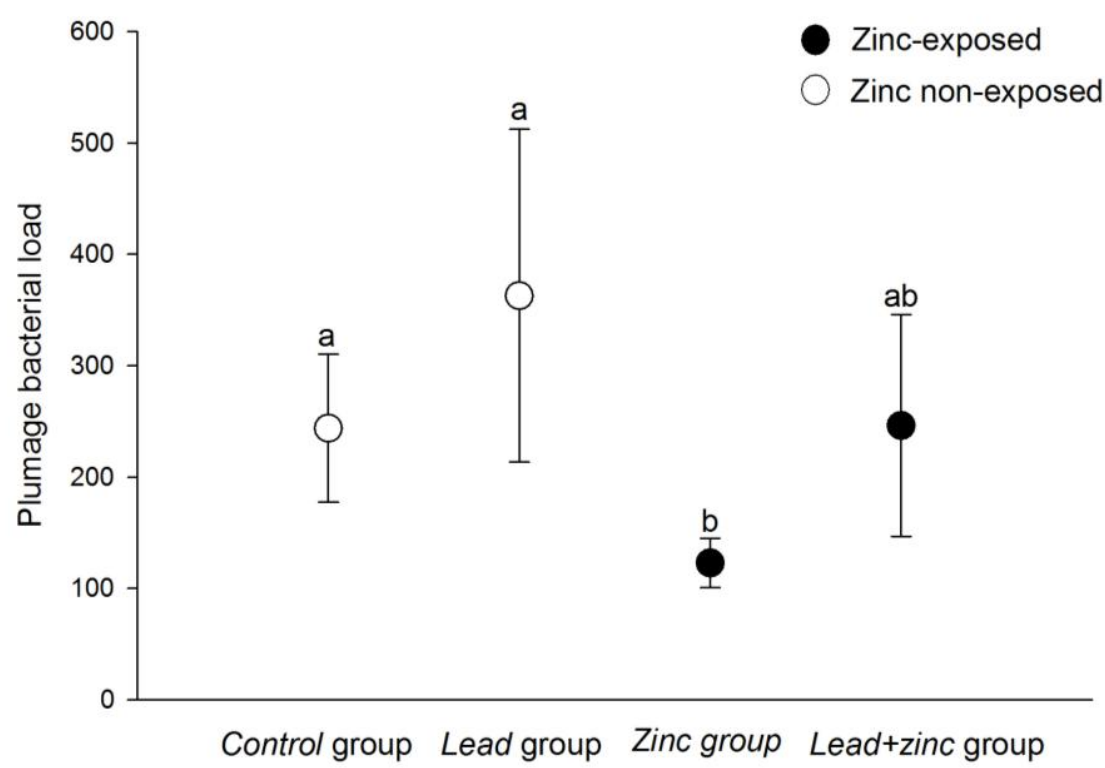

